\title{
化学的共沈法による高保磁力 $\mathrm{Co}-\mathrm{Ni}-\mathrm{Mn}$ スピネルフェライト微粒子の諸特性
}

\author{
Some Properties of Co-Ni-Mn Spinel Ferrite Fine Particles with High Coercivity
}

Prepared by the Chemical Coprecipitation Method

\author{
山元 洋 ・西尾博明・吉田直樹 \\ 明治大学理工学部，川崎市多摩区東三田 1-1-1（†214-8571）
}

H. Yamamoto, H. Nishio, and N. Yoshida

School of Science and Technology, Meiji University, 1-1-1 Higashimita, Tama-ku, Kawasaki 214-8571, Japan.

An experiment was carried out to investigate the effect of $\mathrm{Mn}$ substitution on $\mathrm{Co}-\mathrm{Ni}$ spinel ferrite prepared by the chemical coprecititation method without post-annealing. The chemical coprecipitation compositions were chosen according to the formula $(\mathrm{CoO})_{0.5}(\mathrm{NiO})_{0.5-\mathrm{y}}(\mathrm{MnO})_{\mathrm{y}} \cdot \mathrm{n} / 2\left(\mathrm{Fe}_{2} \mathrm{O}_{3}\right)$, where $\mathrm{y}$ varied between 0 and 0.5 and $\mathrm{n}$ between 2.0 and 2.5. Optimum magnetic properties were achieved with materials whose composition was $(\mathrm{CoO})_{0.5}(\mathrm{NiO})_{0.4}(\mathrm{MnO})_{0.1} \cdot 1.125$ $\left(\mathrm{Fe}_{2} \mathrm{O}_{3}\right)$. The typical magnetic and physical properties are saturation magnetization $\sigma_{\mathrm{s}}=55.5 \times 10^{-6} \mathrm{~Wb} \cdot$ $\mathrm{m} / \mathrm{kg}(44.2 \mathrm{emu} / \mathrm{g})$, coercivity $H_{\mathrm{cJ}}=567.2 \mathrm{kA} / \mathrm{m}(7.12$ kOe), average particle size $D=43 \mathrm{~nm}$, anisotropy constant $K_{1}=+1.36 \times 10^{5} \mathrm{~J} / \mathrm{m}^{3}\left(+1.36 \times 10^{6} \mathrm{erg} / \mathrm{cm}^{3}\right)$, $K_{2}=-11.3 \times 10^{5} \mathrm{~J} / \mathrm{m}^{3}\left(-11.3 \times 10^{6} \mathrm{erg} / \mathrm{cm}^{3}\right)$, anisotropy field $H_{\mathrm{A}} \fallingdotseq 3.56 \mathrm{MA} / \mathrm{m}(44.7 \mathrm{kOe})$. The rotational hysteresis integral $R h$, which is related to the magnetization mechanism of these fine particles, is 1.62 , and it was found that the magnetization mechanism is an incoherent one.

Key words: Co-Ni-Mn spinel ferrite fine particles, chemical coprecipitation method, anisotropy constant, anisotropy field, incoherent rotation mechanism

\section{1. 緒 言}

Coフェライトは他のスピネルフェライトに比べ結晶磁気異方性 定数 $K_{1}$ の值が大きいため，より微細な粒子になっても超常磁性に なりにくく,ナノサイズでも強磁性を保つことが報告されている ${ }^{1)}$ 2),3), 著者らは化学的共沈法による $\mathrm{Co}-\mathrm{Ni}$ 系スピネルフェライト微 粒子について一連の研究を行っており, モル比 $\mathrm{n}$ $\left\{=\mathrm{Fe}^{3+} /\left(\mathrm{Co}^{2+}+\mathrm{Ni}^{2+}\right)\right\}, \mathrm{pH}$ 条件等の作製条件の変化による高保磁力 特性を報告した ${ }^{4)}$. 本研究では, さらに $\mathrm{Co}-\mathrm{Ni}$ スピネルフェライト の一部を $\mathrm{Mn}$ で置換し, モル比 $\mathrm{n}\left\{=\mathrm{Fe}^{3+} /\left(\mathrm{Co}^{2+}+\mathrm{Ni}^{2+}+\mathrm{Mn}^{2+}\right)\right\}, \mathrm{Mn}$ 置換量 $\mathrm{y}, \mathrm{pH}$ 条件の変化により $\mathrm{Co}-\mathrm{Ni}-\mathrm{Mn}$ スピネルフェライトの 磁気特性および物理特性に与える影響を詳細に実験, 検討したの で報告する.

\section{2. 実 験 方 法}

\section{2. $1 \mathrm{Co}-\mathrm{Ni}-\mathrm{Mn}$ フェライト微粒子の作製}

Fig. 1 は Co-Ni-Mn スピネルフェライト微粒子作製のブロック ダイアグラムである．実験に使用した原材料は $\mathrm{FeCl}_{3} \cdot 6 \mathrm{H}_{2} \mathrm{O}$, $\mathrm{CoCl}_{2} \cdot 6 \mathrm{H}_{2} \mathrm{O}, \mathrm{NiCl}_{2} \cdot 6 \mathrm{H}_{2} \mathrm{O}, \mathrm{MnCl}_{2} \cdot 6 \mathrm{H}_{2} \mathrm{O}$ および $\mathrm{NaOH}$ の試薬特

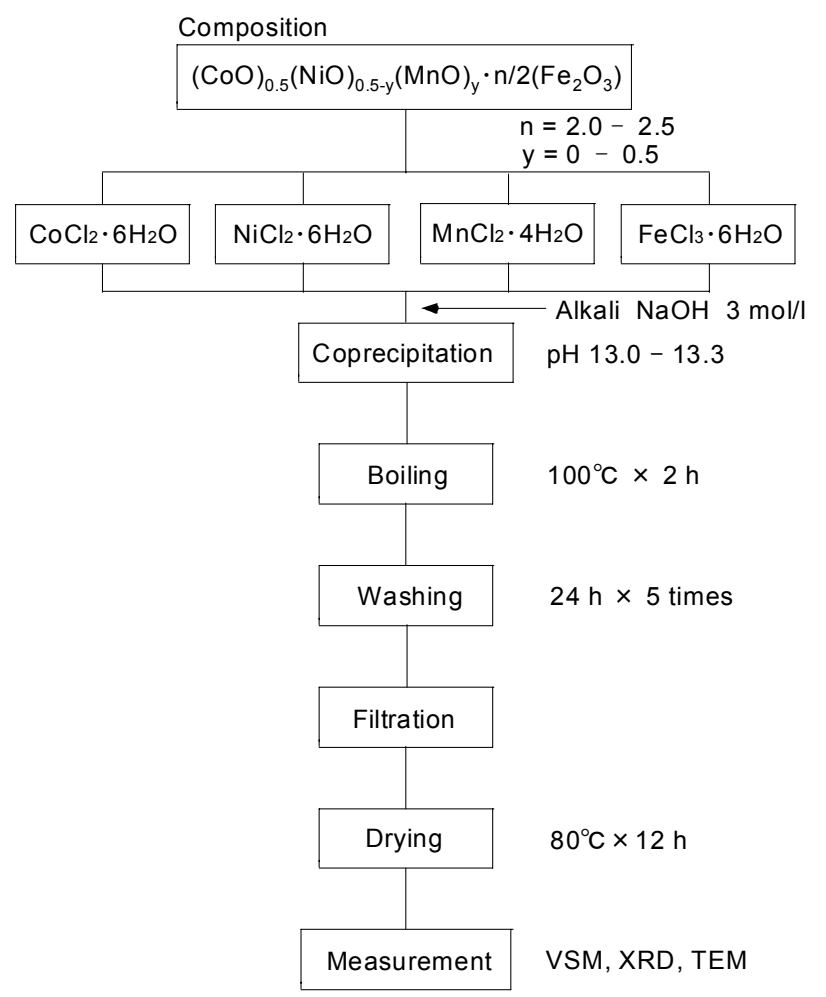

Fig. 1 Block diagram of the preparation of $\mathrm{Co}-\mathrm{Ni}-\mathrm{Mn}$ spinel ferrite fine particles.

級である. 実験は組成式 $(\mathrm{CoO})_{0.5}(\mathrm{NiO})_{0.5-y}(\mathrm{MnO})_{\mathrm{y}} \cdot \mathrm{n} / 2\left(\mathrm{Fe}_{2} \mathrm{O}_{3}\right)$ にお いてモル比 $\mathrm{n}\left\{=\mathrm{Fe}^{3+} /\left(\mathrm{Co}^{2+}+\mathrm{Ni}^{2+}+\mathrm{Mn}^{2+}\right)\right\}$ が 2.0〜2.5 となるように 秤量し, 純水を用いて混合溶液にした. そこに, よく撹拌しながら $\mathrm{NaOH}$ 水溶夜 $(3 \mathrm{~mol} / \mathrm{l})$ を加え, $\mathrm{pH} 13.0 \sim 13.3$ の範囲で共沈を行っ た. その後, 煮沸 $\left(100^{\circ} \mathrm{C} て ゙ 2\right.$ 時間 $)$, 水洗い $(24$ 時間ごとに 5 回 $), ろ$ 過, 乾燥 $\left(80^{\circ} \mathrm{C} て ゙ 12\right.$ 時間)を行い, Co-Ni-Mn スピネルフェライト 微粒子を作製した.

\section{2 磁気シートの作製}

Fig. 2 はトルク測定で用いた磁気シートを作製する際のブロッ クダイアグラムである. まず, 塩化ビニル酶酸ビニル共重合体, シ クロヘキサン, トルエン, メチルエチルケトンを重量比 $1: 6.21$ : $6.21: 2.59$ の割合で混合し, ラッカーを作製した. 次に, $\mathrm{Co}-\mathrm{Ni}-\mathrm{Mn}$ スピネルフェライト微粒子, ラッカー, ガラスビーズの重量比が $1: 4: 8$ となるように混合した. これを， 8 時間の分散後, ドクター 
ブレード法を用いて $15 \mu \mathrm{m}$ の PET フィルム上に塗布し, 800 $\mathrm{kA} / \mathrm{m}(10 \mathrm{kOe})$ の磁界中で配向させ, 乾燥して磁気シートを作製し た.

\section{3 特性評価}

試料の磁気特性は振動試料型磁力計 (VSM)により測定し, 粉末 の結晶構造は X 線回折装置 $(\mathrm{FeK} \alpha$ 使用)により評価し, 粉末の粒 度は透過型電子顕微鏡 (TEM)により観察した. 磁気異方性定数 $\mathrm{K}_{1}$ 及び $\mathrm{K}_{2}$ はトルク磁力計を用いて測定したトルク曲線をフーリ 工解析し，トルクを $L$ 電磁石の角度を $\theta$ として次式から決定した 5).

$$
\begin{aligned}
L= & -\left(K_{1} / 4+K_{2} / 64\right) \sin 2 \theta-\left(3 K_{1} / 8+K_{2} / 16\right) \sin 4 \theta \\
& +\left(3 K_{2} / 64\right) \sin 6 \theta .
\end{aligned}
$$

また, 磁気異方性磁界 $H_{\mathrm{A}}$ は, トルク磁力計を用いて回転ヒ ステリシス損失の磁界依存性から求めた ${ }^{6), 7)}$.

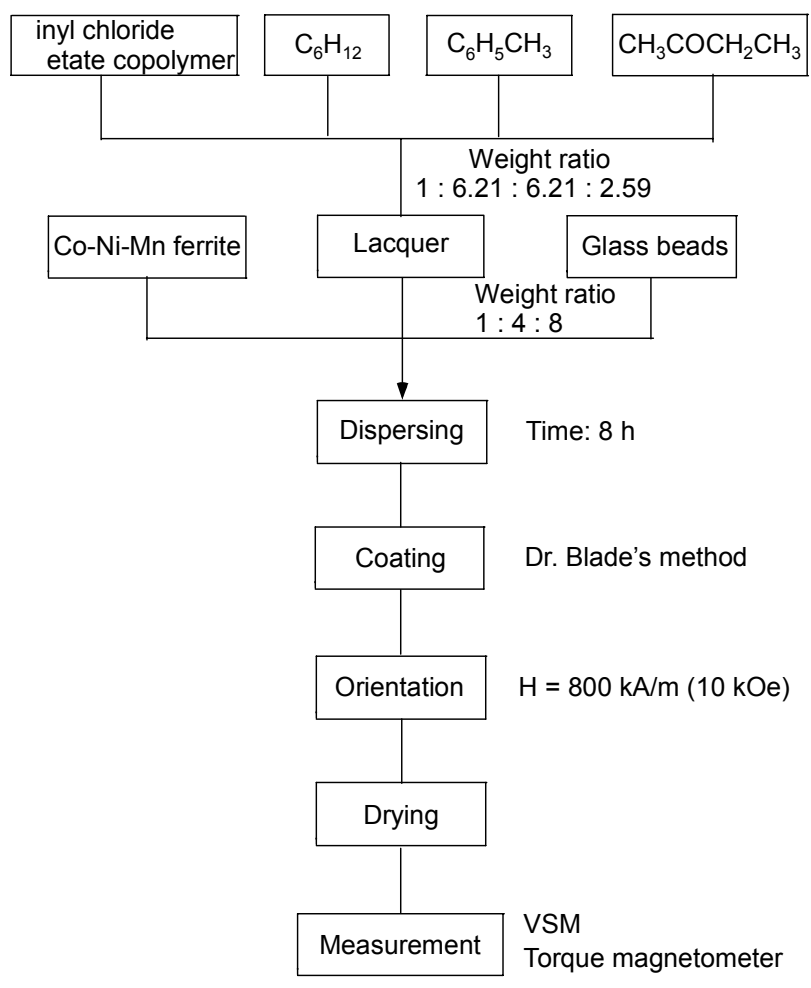

Fig. 2 Block diagram of the preparation of the magnetic sheet.

\section{3. 実験結果ならびに考察}

\section{3. $1 \mathrm{Co}-\mathrm{Ni}-\mathrm{Mn}$ フェライトの磁気特性と結晶構造}

最初に $\mathrm{pH} 13.0$ 一定としてモル比 $\mathrm{n}\left\{=\mathrm{Fe}^{3+} /\left(\mathrm{Co}^{2+}+\mathrm{Ni}^{2+}+\mathrm{Mn}^{2+}\right)\right\}$, $\mathrm{Mn}$ 置換量 $\mathrm{y}$ を変化させたものについて検討した. Fig. 3 は組成式 $(\mathrm{CoO})_{0.5}(\mathrm{NiO})_{0.5 \mathrm{y}}(\mathrm{MnO})_{\mathrm{y}} \cdot \mathrm{n} / 2\left(\mathrm{Fe}_{2} \mathrm{O}_{3}\right)$ においてモル比 $\mathrm{n}$ を $\mathrm{n}=2.0$, $2.25,2.5$ の 3 点を選出し, $\mathrm{Mn}$ 置換量 $\mathrm{y}$ を 0 0.5 として作製した ときの Co-Ni-Mn スピネルフェライト微粒子の磁気特性を示した ものである. 飽和磁化 $\sigma_{\mathrm{s}}$ は $\mathrm{Mn}$ 置換量 $\mathrm{y}$ が増加するにつれて増加 する傾向を示し, モル比 $\mathrm{n}$ が小さくなるにつれて増加する傾向を 示した. 一方, 保磁力 $H_{\mathrm{cJ}}$ は $\mathrm{y}=0.05$ または $\mathrm{y}=0.1$ のとき最大值

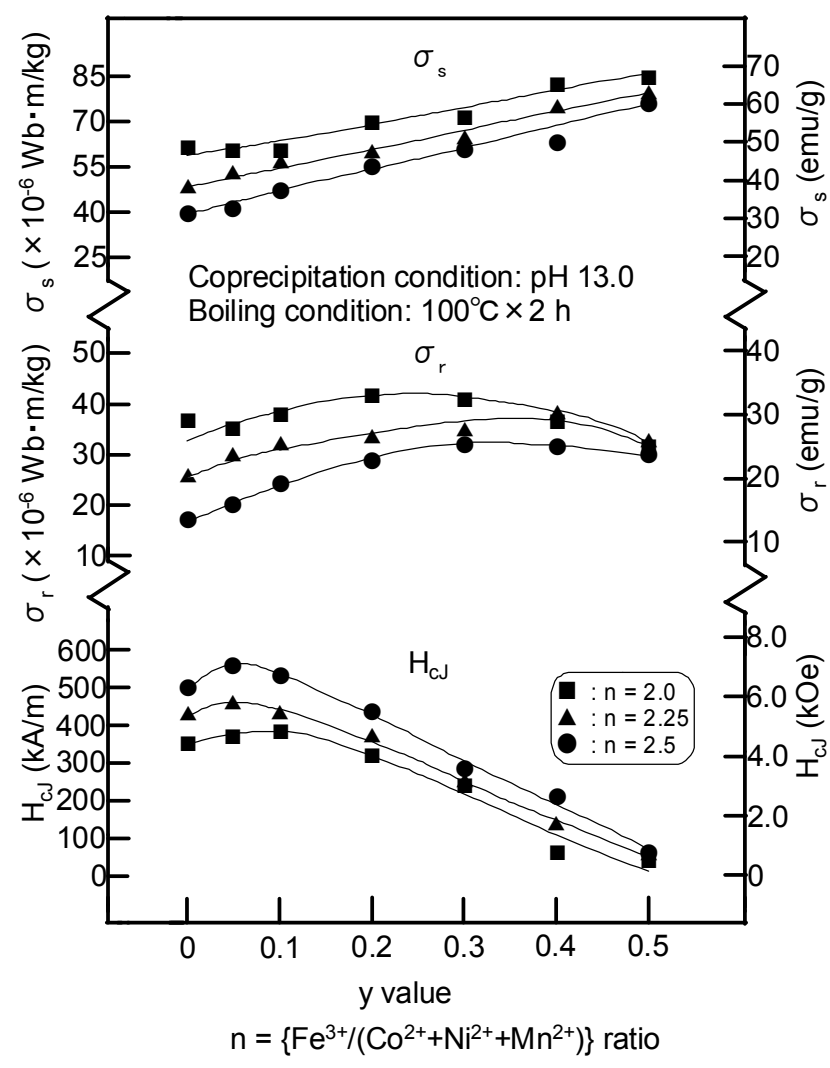

Fig. 3 Magnetic properties of $(\mathrm{CoO})_{0.5}(\mathrm{NiO})_{0.5 y}(\mathrm{MnO})_{\mathrm{y}}$. $\mathrm{n} / 2\left(\mathrm{Fe}_{2} \mathrm{O}_{3}\right)$ fine particles coprecipitated at $\mathrm{pH} 13.0$.

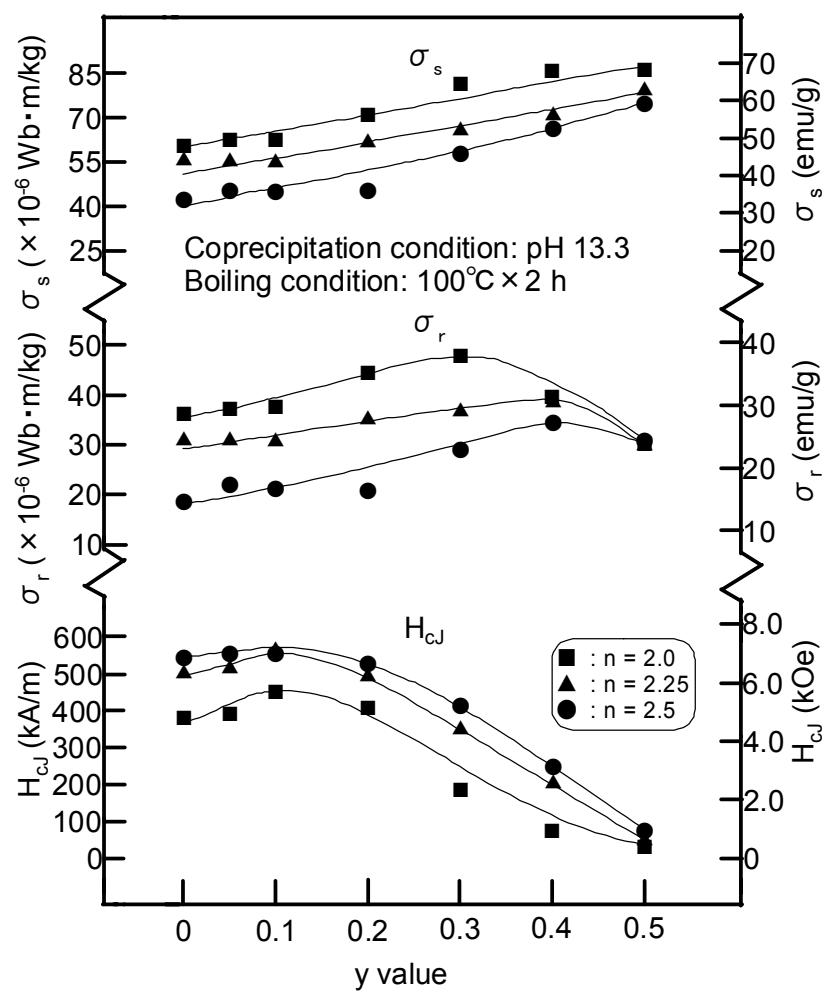

$\mathrm{n}=\left\{\mathrm{Fe}^{3+} /\left(\mathrm{Co}^{2+}+\mathrm{Ni}^{2+}+\mathrm{Mn}^{2+}\right)\right\}$ ratio

Fig. 4 Magnetic properties of $(\mathrm{CoO})_{0.5}(\mathrm{NiO})_{0.5 \mathrm{y}}(\mathrm{MnO})_{\mathrm{y}}$. $\mathrm{n} / 2\left(\mathrm{Fe}_{2} \mathrm{O}_{3}\right)$ fine particles coprecipitated at $\mathrm{pH} 13.3$. 
を示し, その後, 減少する傾向を示した。また, $\mathrm{n}$ に関しては $\mathrm{n}$ が大 きくなるにつれて増加する傾向を示した.

次に, これらの組成において $\mathrm{pH} 13.3$ として作製した Co-Ni-Mn スピネルフェライト微粒子の磁気特性を Fig. 4 に示す. 飽和磁化 $\sigma_{\mathrm{s}}$ およひ残留磁化 $\sigma_{\mathrm{r}}$ は $\mathrm{pH} 13.0$ として作製したときと比べ, ほぼ 同じ傾向を示した. 一方, 保磁力 $H_{\mathrm{c}}$ に関しては高保磁力化するこ とがわかり,$(\mathrm{CoO})_{0.5}(\mathrm{NiO})_{0.4}(\mathrm{MnO})_{0.1} \cdot 1.125\left(\mathrm{Fe}_{2} \mathrm{O}_{3}\right)$ 組成および $(\mathrm{CoO})_{0.5}(\mathrm{NiO})_{0.4}(\mathrm{MnO})_{0.1} \cdot 1.25\left(\mathrm{Fe}_{2} \mathrm{O}_{3}\right)$ 組成では $557 \mathrm{kA} / \mathrm{m}(7.0$ $\mathrm{kOe})$ を超える保磁力を有することがわかった. なお、化学分析の 結果, $\mathrm{pH} 13.0$ 時および $\mathrm{pH} 13.3$ 時ともに仕込み量とほぼ一致した. これらの結果より, 以下では $\mathrm{pH} 13.3$ について述べる.

次に, これらの試料の結晶構造を調べるために X 線回折を行っ た. Fig. 5 に $=2.0,2.25,2.5$ およびy $=0.05,0.5$ 組成において $\mathrm{pH} 13.3$ として作製した試料のX線回折図形を示寸.これらのX線 回折図形より，これらの試料はスピネル単相であることがわかっ た.

次に, モル比nの変化による粒径の変化を調べるためにTEM観 察を行った. Fig. 6 は Mn 置換量 $\mathrm{y}$ を 0.1 一定として $\mathrm{n}=2.0$ およ び 2.25 と変化させたときの TEM 写真を示したものである. 粒子 形態はいずれも立方晶であり, 粒子は $\mathrm{n}$ の増加とともに大きくな る傾向を示した. これらのTEM写真より平均粒径を求めたところ, $\mathrm{n}=2.0$ のときは約 $38 \mathrm{~nm}, \mathrm{n}=2.25$ のときは約 $43 \mathrm{~nm}$ であった. また, 同様に Mn 置換量y の変化の影響を調べるために TEM 観察 を行った. Fig. 7 はモル比 $\mathrm{n}$ を $\mathrm{n}=2.0$ 一定として $\mathrm{y}$ を $0 \sim 0.5$ と変 化させたときのTEM 写真を示したものである. これらのTEM写 真より粒径は $\mathrm{y}=0.1$ のとき最も大きく, その後, $\mathrm{y}$ を増加させるに つれて小さくなる傾向を示した. また, これらのTEM 写真より平 均粒径を求めた図を Fig. 8 に示す. Mn を置換しない $\mathrm{y}=0$ のとき 平均粒径は約 $35 \mathrm{~nm}, \mathrm{y}=0.1$ のとき約 $38 \mathrm{~nm}$, その後, $\mathrm{y}$ を増加さ せるにつれて小さくなり, $\mathrm{y}=0.5$ のとき約 $25 \mathrm{~nm}$ であった.

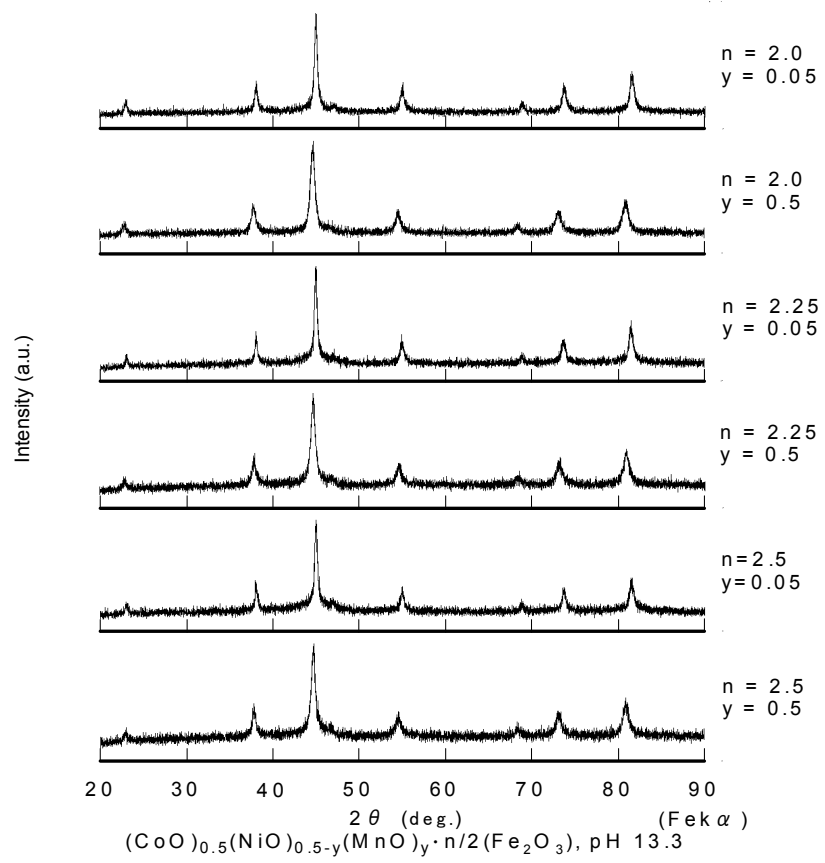

Fig. 5 X-ray diffraction patterns of $\mathrm{Co}-\mathrm{Ni}-\mathrm{Mn}$ spinel ferrite fine particles.
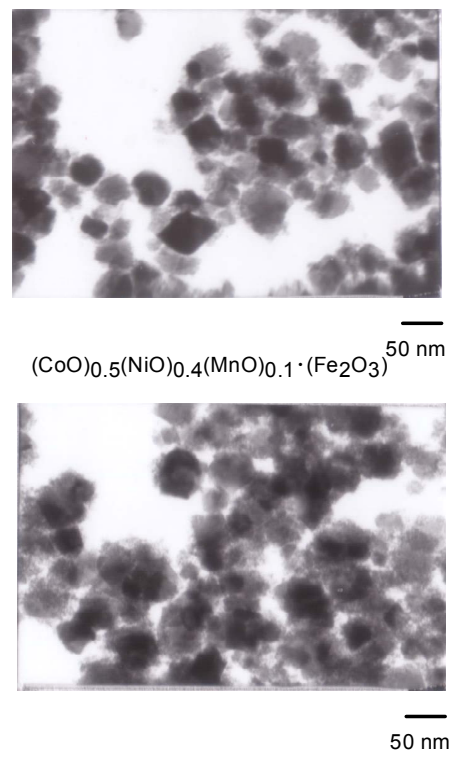

$(\mathrm{CoO})_{0.5}(\mathrm{NiO})_{0.4}(\mathrm{MnO})_{0.1} \cdot 1.125\left(\mathrm{Fe}_{2} \mathrm{O}_{3}\right)$

Coprecipitation condition: $\mathrm{pH} 13.3$

Fig. 6 TEM photographs of $\mathrm{Co}-\mathrm{Ni}-\mathrm{Mn}$ spinel ferrite fine particles with various $\mathrm{n}$ values.
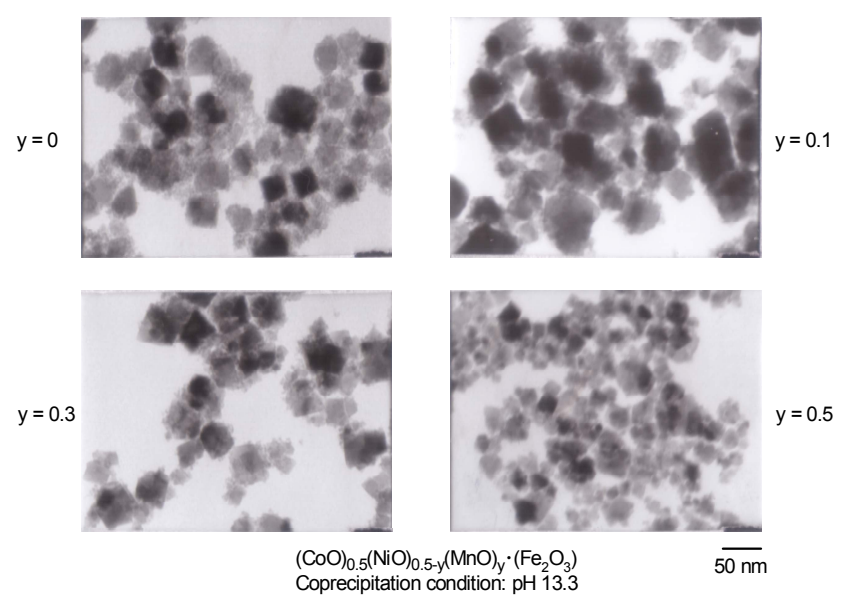

Fig. 7 TEM photographs of $\mathrm{Co}-\mathrm{Ni}-\mathrm{Mn}$ spinel ferrite fine particles with various y values.

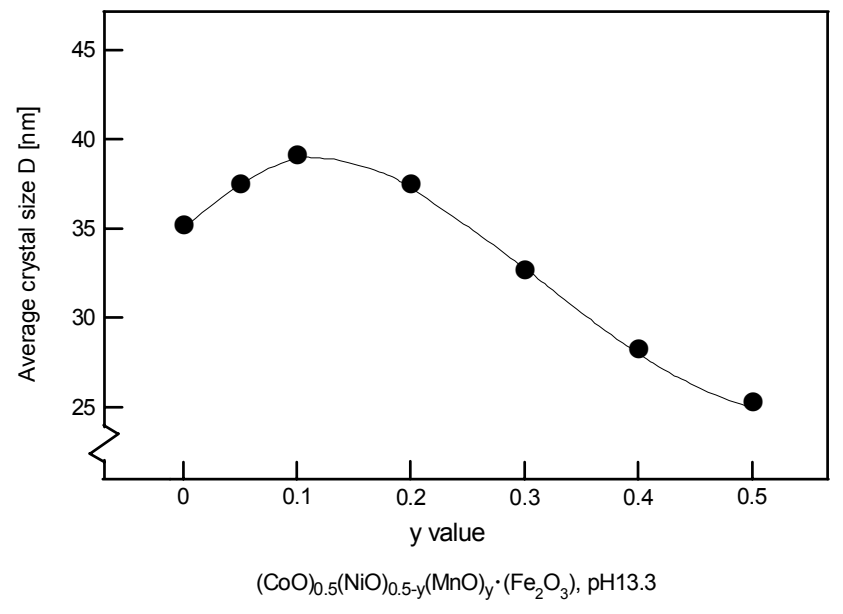

Fig. 8 Average particle size of $\mathrm{Co}-\mathrm{Ni}-\mathrm{Mn}$ spinel ferrite fine particles with various y values. 


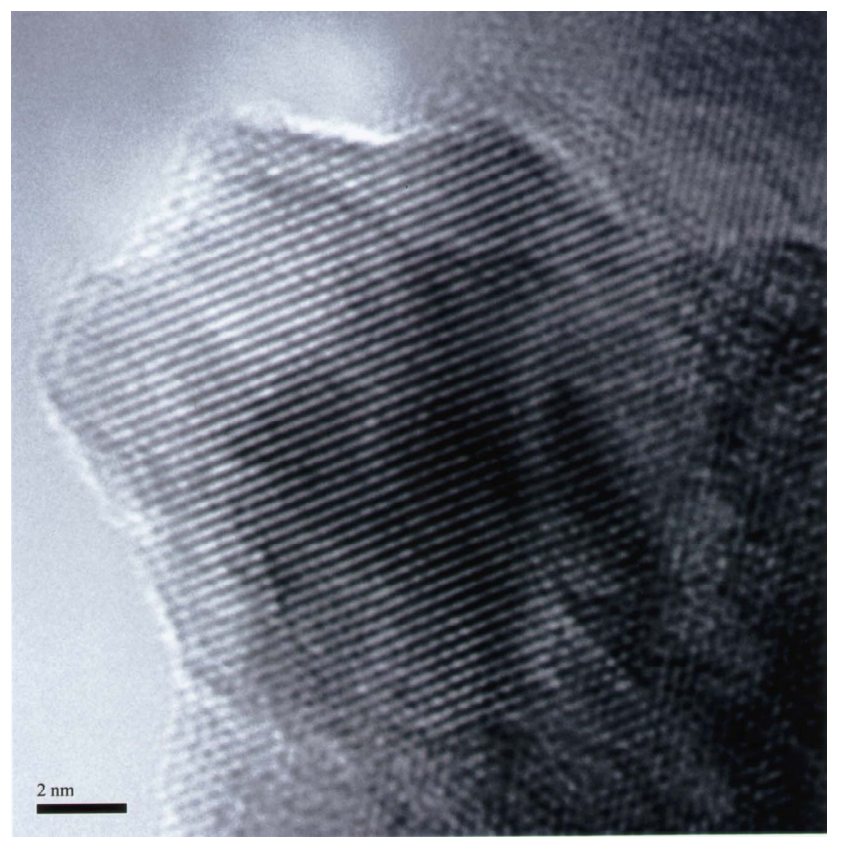

$(\mathrm{CoO})_{0.5}(\mathrm{NiO})_{0.4}(\mathrm{MnO})_{0.1} \cdot 1.125\left(\mathrm{Fe}_{2} \mathrm{O}_{3}\right)$

Coprecipitation condition: $\mathrm{pH} 13.3$

Fig. 9 High-resolution TEM photograph of Co-Ni-Mn spinel ferrite fine particles.

Fig. 9 は $(\mathrm{CoO})_{0.5}(\mathrm{NiO})_{0.4}(\mathrm{MnO})_{0.1} \cdot 1.125\left(\mathrm{Fe}_{2} \mathrm{O}_{3}\right)$ 組成の高分解能 TEM 写真である. この TEM 写真より格子線が明確に確認できる ことから, この Co-Ni-Mn スピネルフェライト微粒子は固溶体と して生成されていることがわかった。

\section{2 Co- $\mathrm{Ni}-\mathrm{Mn}$ フェライトの異方性定数ならびに異方性磁界}

まず, 異方性定数並びに異方性磁界を求めるために, 高保磁力特 性を示した $(\mathrm{CoO})_{0.5}(\mathrm{NiO})_{0.4}(\mathrm{MnO})_{0.1} \cdot 1.125\left(\mathrm{Fe}_{2} \mathrm{O}_{3}\right)$ 組成の粉末を用 いて磁気シートを作製した. Fig. 10 は $2.15 \mathrm{MA} / \mathrm{m}(27 \mathrm{kOe})$ の磁界 中で測定したトルク曲線である. これは立方晶の $\left(\begin{array}{llll}1 & 1 & 0\end{array}\right)$ 面で測定 したときの典型的なトルク曲線である5).このトルク曲線をフーリ 工解析し, 異方性定数を求めたところ $K_{1}=+1.36 \times 10^{5} \mathrm{~J} / \mathrm{m}^{3}$ $\left(+1.36 \times 10^{6} \mathrm{erg} / \mathrm{cm}^{3}\right), K 2=-11.3 \times 10^{5} \mathrm{~J} / \mathrm{m}^{4}\left(-11.3 \times 10^{6}\right.$ $\left.\mathrm{erg} / \mathrm{cm}^{3}\right)$ であった. なお，シートに磁界を印加した方向とその垂直 方向との配向度は約 1.1 である. また, これらの值はバルクの $\mathrm{CoO} \cdot \mathrm{Fe}_{2} \mathrm{O}_{3}$ 化合物の異方性定数 $K_{1}=2 \sim 3 \times 10^{5} \mathrm{~J} / \mathrm{m}^{3}\left(2 \sim 3 \times 10^{6}\right.$ $\left.\left.\mathrm{erg} / \mathrm{cm}^{3}\right), 8,9\right)$ と比べると小さい值となった.

トルクを $L$, シートを配向した方向を $0^{\circ}$ とし, 電磁石の角度 を $\theta$ としたとき，回転ヒステリシス損失 $W_{\mathrm{r}}$ は次式で表される5 .

$$
W_{\mathrm{r}}=\int L \cdot \mathrm{d} \theta .
$$

磁化反転機構に関連する回転ヒステリシス積分 $R h$ は単位体積当 たりの飽和磁化を J主とすると次式から計算される ${ }^{6}$.

$$
R h=\int W_{\mathrm{I}} / J_{\mathrm{s}} \mathrm{d}(1 / H) .
$$

以上より求めた $W_{\mathrm{r}} / J_{\mathrm{s}}$ の磁界依存性を Fig. 11 に示す. $W_{\mathrm{r}} / J_{\mathrm{s}}$ を 2.15 $\mathrm{MA} / \mathrm{m}(27 \mathrm{kOe})$ まで測定した結果, 異方性磁界 $H_{\mathrm{A}}$ を外挿值より求 めると $H_{A} \fallingdotseq 3.56 \mathrm{MA} / \mathrm{m}(44.7 \mathrm{kOe})$ となり, 高い異方性磁界を有 することがわかった. このため, 高い保磁力が得られたと考えられ

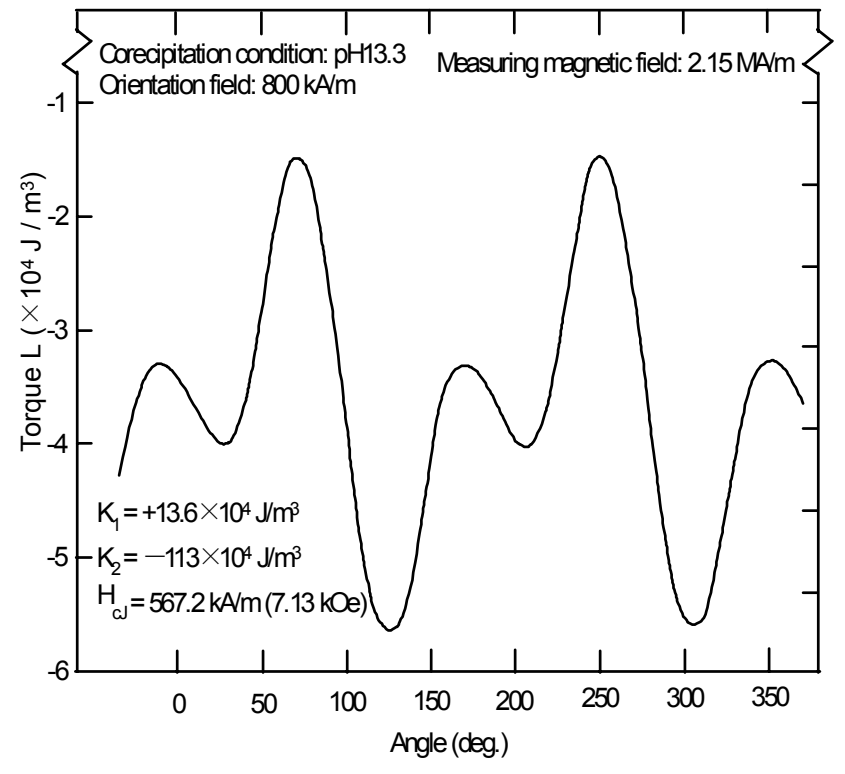

Fig. 10 Torque curve of an oriented sheet sample prepared by using $(\mathrm{CoO})_{0.5}(\mathrm{NiO})_{0.4}(\mathrm{MnO})_{0.1} \cdot 1.125\left(\mathrm{Fe}_{2} \mathrm{O}_{3}\right)$ fine particles.

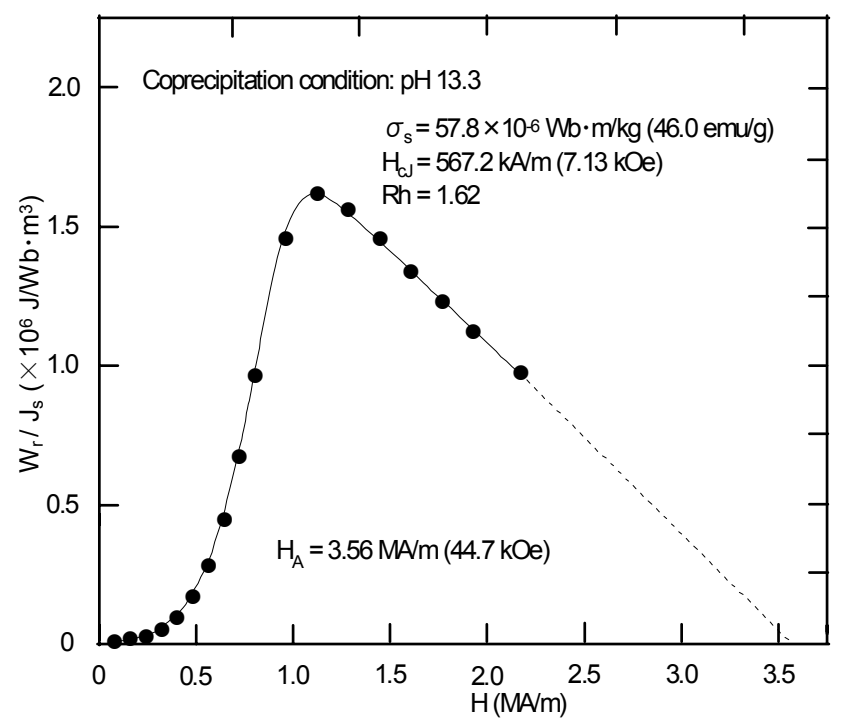

Fig. 11 Rotational hysteresis loss $W_{1} / J_{S}$ of a sheet sample prepared by using $(\mathrm{CoO})_{0.5}(\mathrm{NiO})_{0.4}(\mathrm{MnO})_{0.1}$ • $1.125\left(\mathrm{Fe}_{2} \mathrm{O}_{3}\right)$ fine particles.

る. また, 磁化機構に関連する回転ヒステリシス積分 $R h$ は 1.62 で, 非一斉回転磁化機構であることがわかった。

\section{4. 結 言}

$\mathrm{Co}-\mathrm{Ni}-\mathrm{Mn}$ スピネルフェライト微粒子をモル比 $\mathrm{n}\{=$ $\left.\mathrm{Fe}^{3+} /\left(\mathrm{Co}^{2+}+\mathrm{Ni}^{2+}+\mathrm{Mn}^{2+}\right)\right\}, \mathrm{Mn}$ 置換量 $\mathrm{y}$ および $\mathrm{pH}$ 条件を変化させ て化学的共沈法により作製した. これらの試料の結晶性, 磁気特性 等を調べた結果をまとめると以下のとおりである.

(1) $(\mathrm{CoO})_{0.5}(\mathrm{NiO})_{0.5 \mathrm{y}}(\mathrm{MnO})_{\mathrm{y}} \cdot \mathrm{n} / 2\left(\mathrm{Fe}_{2} \mathrm{O}_{3}\right)$ 組成の試料をモル比 $\mathrm{n}\left\{=\mathrm{Fe}^{2+} /\left(\mathrm{Co}^{2+}+\mathrm{Ni}^{2+} \mathrm{Mn}^{2+}\right)\right\}$ を $\mathrm{n}=2.0 \sim 2.5, \mathrm{Mn}$ 置換量 $\mathrm{y}$ を $\mathrm{y}=0 \sim$ 
0.5, $\mathrm{pH}$ を 13.0 および 13.3 として作製した. これらの試料のX線 回折ではスピネル単相であることがわかった. また, pH13.0 時に 比べ, $\mathrm{pH} 13.3$ となると高保磁力化することが知られ. 最も良好な 磁気特性を示したのは $(\mathrm{CoO})_{0.5}(\mathrm{NiO})_{0.4}(\mathrm{MnO})_{0.1} \cdot 1.125\left(\mathrm{Fe}_{2} \mathrm{O}_{3}\right)$ 組成 のときで，そのときの磁気特性および物理特性は飽和磁化 $\sigma_{\mathrm{s}}=$ $55.5 \times 10^{-6} \mathrm{~Wb} \cdot \mathrm{m} / \mathrm{kg}(44.2 \mathrm{emu} / \mathrm{g})$, 残留磁化 $\sigma_{\mathrm{r}}=30.2 \times 10^{-6}$ $\mathrm{Wb} \cdot \mathrm{m} / \mathrm{kg}(24.1 \mathrm{emu} / \mathrm{g})$, 保磁力 $H_{\mathrm{cJ}}=567.2 \mathrm{kA} / \mathrm{m}(7.12 \mathrm{kOe})$, 平 均粒径 $D=43 \mathrm{~nm}$ であった. また, 組成を変化させることにより 保磁力, 粒径が変化することがわかった.

(2) $\quad(\mathrm{CoO})_{0.5}(\mathrm{NiO})_{0.4}(\mathrm{MnO})_{0.1} \cdot 1.125\left(\mathrm{Fe}_{2} \mathrm{O}_{3}\right)$ 組成を $\mathrm{pH} 13.3$ とし て作製した試料を用いて磁気シートを作製した. その磁気シート のトルク曲線より異方性定数 $K_{1}$ および $K_{2}$ を算出すると, $K_{1}=$ $+1.36 \times 10^{5} \mathrm{~J} / \mathrm{m}^{3}\left(+1.36 \times 10^{6} \mathrm{erg} / \mathrm{cm}^{3}\right), K_{2}=-11.3 \times 10^{5} \mathrm{~J} / \mathrm{m}^{4}$ $\left(-11.3 \times 10^{6} \mathrm{erg} / \mathrm{cm}^{3}\right)$ であった. また, 同トルク曲線から回転ヒス テリシス損失を評価し, 異方性磁界 $H_{\mathrm{A}}$ を求めると, 約 $3.56 \mathrm{MA} / \mathrm{m}$ (44.7 kOe)であった.

\section{References}

1) M. Rejendran, R. C. Pullar, A. K. Bhattacharya, D. Das and S. N. Chintalapudi : J. Magn. Magn. Mater. , 232, 71 (2001).

2) C. N. Chinnasamy, B. Jeyadevan, O. Perales-Perez, K. Shinoda, K. Tohji and A. Kasuya : IEEE Trans. Magn., 38, 2640 (2002).

3) Hiroshi Yamamoto, Hiroaki Nishio and Naoki Yoshida : $J$. Magn. Soc. Jpn. , 28, 102 (2004).

4) Hiroshi Yamamoto and Yukihiro Nissato : IEEE Trans. Magn. , 38, 3488 (2002).

5) S. Chikazumi : Physics of Ferromagnetism, vol. II, p. 13 (Syokabo Co., Ltd., Tokyo, 1984).

6) I. S. Jacobs, F. E. Luborsky : J. Appl. Phys. , 28, 467 (1957).

7) D. M. Paige, S. R. Hoon and B. K. Tanner : IEEE Trans. Magn. 20, 1852 (1984).

8) K. Ohta : The base of the magnetism engineering, vol. I, p. 186 (Kyoritushuppan Co., Ltd., Tokyo).

9) H. Szydlowski : Acta Phys. Polon. , 43, 399 (1973).

2004 年 10 月 5 日受理， 2005 年 1 月 14 日採録 